Retraction

\title{
Retracted: Essential Oils Loaded in Nanosystems: A Developing Strategy for a Successful Therapeutic Approach
}

\author{
Evidence-Based Complementary and Alternative Medicine
}

Received 17 December 2020; Accepted 17 December 2020; Published 19 February 2021

Copyright (๑) 2021 Evidence-Based Complementary and Alternative Medicine. This is an open access article distributed under the Creative Commons Attribution License, which permits unrestricted use, distribution, and reproduction in any medium, provided the original work is properly cited.

Evidence-Based Complementary and Alternative Medicine has retracted the article titled "Essential Oils Loaded in Nanosystems: A Developing Strategy for a Successful Therapeutic Approach" [1] due to high level of text similarity with previously published articles [2-6], of which [2, 4] were not cited.

A reassessment of the article concluded that large areas of overlapping text were identified throughout the article, especially in Section 5, "EO-Loaded Nanodelivery Systems." The article is therefore being retracted with the agreement of the editorial board and the authors.

\section{References}

[1] A. R. Bilia, C. Guccione, B. Isacchi, C. Righeschi, F. Firenzuoli, and M. C. Bergonzi, "Essential Oils Loaded in Nanosystems: A Developing Strategy for a Successful Therapeutic Approach," Evidence-Based Complementary and Alternative Medicine, vol. 2014, Article ID 651593, 14 pages, 2014.

[2] A. S. Pedro, I. E. Santo, C. Detoni, C. V. da Silva, and E. Cabral-Albuquerque, "The use of nanotechnology as an approach for essential oil-based formulations with antimicrobial activity," Microbial Pathogens and Strategies for Combating Them: Science, Technology and Education, Formatex, Spain, 2013, https://www.researchgate.net/ publication/299398183_The_use_of_nanotechnology_as_ an_approach_for_essential_oil-based_formulations_with_ antimicrobial_activity.

[3] F. Bakkali, S. Averbeck, D. Averbeck, and M. Idaomar, "Biological effects of essential oils-a review," Food and Chemical Toxicology, vol. 46, no. 2, p. 446, 2008.

[4] S. Varona, A. Martin, and M. J. Cocero, "Liposomal incorporation of lavandin essential oil by a thin-film hydration method and by particles from gas-saturated solutions," Industrial \& Engineering Chemistry Research, vol. 50, no. 4, pp. 2088-2097, 2011.
[5] F. Lai, C. Sinico, A. De Logu, M. Zaru, R. H. Müller, and A. M. Fadda, "SLN as a topical delivery system for Artemisia arborescens essential oil: in vitro antiviral activity and skin permeation study," International Journal of Nanomedicine, vol. 2, no. 3, pp. 419-425, 2007, https://www.ncbi.nlm.nih.gov/ pmc/articles/PMC2676653/pdf/ijn-2-419.pdf.

[6] C. Sinico, A. De Logu, F. Lai, D. Valenti, M. Manconi, G. Loy, L. Bonsignore, and A. M. Fadda, "Liposomal incorporation of Artemisia arborescens L. essential oil and in vitro antiviral activity," European Journal of Pharmaceutics and Biopharmaceutics, vol. 59, no. 1, pp. 161-168, 2005. 